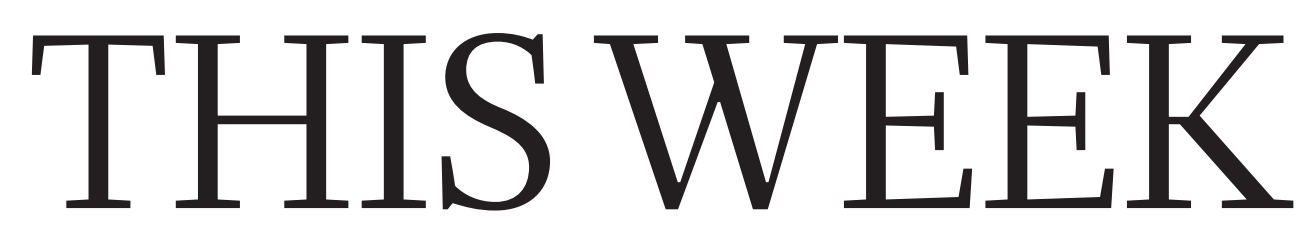

EDITORIALS

FUTURE-PROOF Short-term solutions to long-term issues p.164
WORLD VIEW Business must pull up its sustainable Socks p.165
SEA ME? Cuttlefish switch off to evade marine predators $\mathbf{p} . \mathbf{1 6 6}$

\title{
Fetal tissue research under threat
}

The US Senate has just voted to defund one of the providers of aborted fetal tissue for research. Such research is too valuable to become embroiled in the bitter abortion debate.

$\mathrm{W}$ hen a journalist invites scientists to discuss their work in the pages of Nature, it is rare to encounter a resounding silence. But that was the case when our reporter reached out to biologists in the United States this autumn to ask about the value and applications of their research with human fetal tissue. Just two of the 18 scientists we contacted were willing to go on the record with details of their work.

The reticence is understandable. A hostile political climate surrounds this research in the United States, where the release in July of covertly filmed videos ignited a firestorm of controversy.

Made by anti-abortion campaigners, posing as executives of a fictional biological-supply company, the videos showed senior physicians from the Planned Parenthood Federation of America frankly discussing their supply of legally aborted human fetal tissue for research.

The videos insinuated that the non-profit health-care provider was breaking the law by supplying the fetal tissue to biological-products companies for financial gain. But despite the numerous leading questions, the videos show no law-breaking. In exchange for the fetal tissue, the organization received only legally allowable costs: less than US\$100 for each specimen, at $1 \%$ of its 700 clinics. If Planned Parenthood, which mainly provides contraception, cancer screening and other important health care, was seeking to get rich, it chose a strange way to do so.

That has not stopped Republican politicians from seizing on the videos to make repeated, inaccurate and inflammatory accusations. Presidential hopeful Marco Rubio, a US senator from Florida, charged, with utterly no evidence, that the collection of fetal tissue has "created an incentive for people to be pushed into abortions so that those tissues can be harvested and sold for a profit". Ted Cruz, a US senator from Texas who is also contending for the Republican presidential nomination, declared that Planned Parenthood is "an ongoing criminal enterprise".

It is not surprising then that, since July, even the small number of Planned Parenthood clinics supplying fetal tissue has dwindled. Or that when an unhinged gunman launched a murderous rampage last month, he chose a Planned Parenthood clinic in Colorado as a target.

Nor is it surprising that US scientists who use fetal tissue are choosing to stay silent about the value of their work rather than to defend it publicly and face the real possibility of physical attack. (One scientist told The New York Times that in response to threats against him his institution had posted a guard outside his lab.) The two US-based biologists who did speak to Nature should be applauded for their courage.

As the News Feature on page 178 shows, research that uses fetal tissue is worth defending. And there are ways in which the scientific community can rally round without putting individuals at risk. Admirably, the Association of American Medical Colleges (AAMC) is showing the way. The AAMC released a statement last week signed by 58 academic medical centres, scientific societies and allied groups.
The statement outlined the medical advances that have been made possible by fetal tissue, and described the value of its current applications in areas such as developmental biology and research on infectious diseases. The authors wrote of their "grave concerns" about the numerous legislative proposals now in play in the US Congress and in a dozen states - proposals that would restrict or prohibit fetal tissue research. They warned eloquently that the pro-
"It is time for a de-escalation of the rhetoric and the creation of a space for calm and rational discourse." larger politics of division that has taken hold United States, and which has worsened alarmingly in recent months. It is time for a de-escalation of the rhetoric and the creation of a space for calm and rational discourse.

In the case at hand, that could begin with greater separation of the issues of fetal tissue research and abortion. Clearly, there is fair, honest and understandable disagreement on the morality of the latter. In a democracy, opponents of abortion are free to do their best within the law to change the law. But nobody benefits when they target by proxy an activity that is tangential to the act that they abhor and that is doing a great deal to advance our understanding of health and disease.

\section{Stem the tide}

\section{Japan has introduced an unproven system to make patients pay for clinical trials.}

\footnotetext{
Tapan has been working feverishly to stay at the cutting edge of research and clinical applications in regenerative medicine. It has invested billions of yen in induced pluripotent stem (iPS) cells made by reprogramming an individual's adult cells so that they can develop into any body tissue - and has overhauled its drug regulations to create a fast track to bring regenerative therapies to market.

The strategy is working, up to a point - in September, the first treatments were approved under the new law. According to bullish regenerative-medicine firms in Japan, the scheme is the fastest way to meet patients' needs. Without it, they argue, treatments get bogged down in phased clinical trials that can take several years and cost hundreds
} 